\title{
The Impact of Online Gaming Addiction On Behavior Change Among Adolescents
}

\author{
Andi Sri Purnama Danianti ${ }^{1}$, Tenriwati ${ }^{2}$, Amirullah ${ }^{3 *}$ \\ ${ }^{1}$ Nursing Student, Stikes Panrita Husada Bulukumba, Indonesia \\ ${ }^{2,3}$ Department of Nursing Stikes Panrita Husada Bulukumba, Indonesia
}

Corresponding author: Amirullah

Email: nersamirullah@gmail.com

\begin{abstract}
Online game addiction is a bad habit that can damage the health of ourselves and others, dependence on online games will attack our vision if overused and can also affect our behavior. This habit does not only occur in adults but has spread to adolescents and even elementary school students. The purpose of this study is to know online game addiction to behavior change among adolescents at SMPN 1 Bulukumba in 2020. This research uses quantitative methods. The research subjects were 32 respondents who were selected using purposive sampling in data collection, the researcher used a questionnaire and an interview late. The analysis in this study used Analytical Observational and this study used the Chi Square test. The results of the analysis used the Chi Square test statistical test with a value $(\alpha=0.05)$. Based on the results of this test, the value of $\rho$ is 0.005 , thus $\rho<\alpha(0.005<0.05)$, so Ho is rejected and $\mathrm{Ha}$ is accepted. The conclusion of this study is that there is a relationship with online game addiction on behavior change among adolescents at SMPN 1 Bulukumba in 2020. Researchers suggest that the results of this study can be used as a reference.
\end{abstract}

\section{Keywords: Online Game Addiction, Behavior Change}




\section{PENDAHULUAN}

WHO (World Health Organizations) menetapkan bahwa kecanduan game online merupakan penyakit gangguan mental. Game online ini merupakan salah satu pilihan bagi kalangan remaja untuk menghabiskan waktu senggang dalam bermain game. Seiring kemajuan teknologi sudah semakin berkembang di seluruh dunia, tidak hanya di kota-kota besar dan kota kecil dalam 5 tahun terahir, permainan modern ini atau sering kita sebut dengan game online sudah sangat mendunia di berbagai daerah (Wajo, Selatan, Online, \& Bimbingan, 2019).

Di seluruh dunia, smartphone digunakan oleh 1,85 milyar orang pada tahun 2014. Jumlah ini diperkirakan akan 2,32 milyar pada 2017 dan 2,87 milyar pada tahun 2020 (statista, 2017). Pada tahun 2015 rata-rata 54\% diseluruh 21 negara berkembang dan Negara seperti Malasyia, Brazil berkembang dan sebagai perbandingan rata-rata 87\% dilaporkan sama di 11 negara maju termasuk Amerika, Kanada, dan $\operatorname{Eropa}(\mathrm{Seo}$, n.d.). Di Indonesia sendiri kecanduan game online juga sering terjadi, yang sering mengalami kecanduan itu kebayakan dari kaum laki-laki di bandingkan dengan perempuan. dari berbagai kasus yang sering kita lihat dari media kasus kecanduan game online tersebut ini dapat mengakibatan dikalangan remaja yang harus mengorbankan waktu hanya dengan bermain game online secara terus menerus (Sipahutar, 2013).

Penelitian ini bertujuan untuk mengetahui hubungan antara kecanduan game online smarthphone dengan perilaku agresif pada siswa. Sampel pada penelitian ini adalah siswa MTSN 1 Kampar, jumlah sampel dalam penelitian ini sebanyak 42 siswa yang didapat dengan menggunakan teknik purposive sampling (Wahidah, 2019). Cooper (2000) mengemukakan bahwa kecanduan dalam bentuk perubahan perilaku yang didorong dari rasa ketergantungan yang tinggi akan hal yang disenangi sehingga seseorang bisa dikatakan kecanduan jika meraka melakukan hal yang sama dengan cara berulang-ulang bahkan lebih dari kemampuannya. Seseorang yang kecanduan game online dalam kurung waktu seminggu dia bisa menghabiskan waktu sebanyak 20 jam atau rata-rata pecandu game kadang menghabiskan waktu $\pm 15-20$ jam dalam waktu seminggu, sehingga bisa dikatakan dikalangan remaja yang sedang bermain game online kadang menghabiskan waktu sekitar 3-4 jam dalam sehari (Rahma, Psikologi, Psikologi, \& Surakarta, 2018).

Seorang ahli pakar psikologi di Amerika David Greenfield, mengemukakan bahwa ada sekitar $6 \%$ data dari pengguna internet yang mengalami kecanduan game online. Dimana 
gamer mengalami gejala yang sama dengan kecanduan dengan obat bius, yaitu dimana seorang yang bermain game online ini lupa waktu dalam bermain. Kebayakan orang yang kecanduan game online ini dikarenakan tidak menemukan kepuasan dalam permainan di dunia nyata (Syahran, 2015).

Perilaku demikian yang menyebabkan salah satu perilaku yang maladaptive (tidak sesuai). Perilaku maladaptive ini merupakan perilaku yang tidak sesuai dengan situasi sosial yang ada disekitar individu tersebut dan apabila perilaku yang tidak sesuai ini dibiarkan berkembang di dalam diri remaja, maka akan dikhawatirkan akan menjadi kebiasaan yang akan muncul secara terus-menerus jika remaja ini dewasa nanti (Habsy, 2017). Perilaku individu seseorang kecenderungan munul sejak lahir untuk tumbuh dan beraktualisasi, namun seiring teknologi yang semakin berkembang remaja ini semakin susah di atur bagaimana cara mendidik pola perilaku mereka sejak dini (Gunawan, 2018).Berdasarkan survey awal yang dilakukan peneliti didapatkan jumlah keseluruhan siswa SMPN 1 Bulukumba sebanyak 339 siswa. Jumlah kelasnya ada 35 kelas, masing-masing kelas terdiri dari 31 sampai 32 siswa setiap kelas. Dan jumlah siswa di kelas yang akan di teliti yakni kelas VII yang terdiri dari 32 orang.

Berdasarkan hasil wawancara yang dilakukan kepada siswa/siswi kelas VII ditemukan informasi bahwa siswa tersebut sering bermain game online dan siswa laki-laki sebanyak 20 orang dan siswi perempuan sebanyak 12 orang yang bermain game online. Adapun jenis game online yang sering dimainkan yaitu Free fire dan Mobile Lagend dan game ini merupakan permainan yang sedang populer baik dikalangan remaja dan dewasa. Dimana dikalangan remaja ini sering memainkan game sehabis pulang dari sekolah dan rata-rata remaja banyak menghabisan waktu bermain game sebanyak 1-5 jam/hari, yang paling dominan bermain game yaitu laki-laki dibandingkan dengan perempuan. Jika mereka sedang asyik bermain game biasanya mereka melupakan waktu dan aktivitas yang seharusnya dilakukan oleh para remaja termasuk belajar dan mengerjakan tugas-tugas dari sekolah dan disini nampak terjadi perubahan perilaku dikalangan remaja tersebut.

Berdasarkan urian diatas terkait tentang banyaknya dikalangan remaja yang sudah kecanduan bermain game online sampai-sampai lupa untuk mengerjakan tugas dari sekolahnya dan disini saya tertarik melakukan penelitian mengenai. Dampak kecanduan game online terhadap perubahan perilaku dikalangan remaja. Dimana saya berencana untuk 
melakukan penelitian disalah satu sekolah SMP yang berada di Bulukumba yakni SMPN 1 Bulukumba.

\section{METODE PENELITIAN}

\section{Desain Penelitian}

Desain penelitian mengacu pada jenis atau macam penelitian yang dipilih untuk mencapai tujuan penelitian, serta berperan sebagai alat dan pedoman untuk mencapai tujuan tersebut. Adapun penelitian yang digunakan dalam penelitian ini adalah kuantitatif dengan metode penelitian Cross Sectional dengan menggunakan desain penelitian observasional analitik untuk mengungkapkan hubungan.

\section{Populasi dan Teknik Sampel}

Populasi adalah wilayah generalisasi yang terdiri atas: objek/subjek yang mempunyai kualitas dan karakteristik tertentu yang ditetapkan oleh peneliti untuk dipelajari dan kemudian ditarik kesimpulannya (Sugiyono, 2014). Populasi dalam penelitian ini adalah semua siswa yang berada di SMP Negeri 1 Bulukumba 339 orang.Sampel adalah bagian dari jumlah karakteristik yang dimiliki oleh populasi tersebut (Sugiyono, 2017). Sedangkan Menurut (Hidayat, 2014) sampel merupakan kriteria dimana subjek penelitian mewakili sampel penelitian yang memenuhi syarat sebagai sampel. Jumlah sampel yang akan diteliti dalam penelitian ini yaitu sebanyak 32 responden.

\section{Instrumen Pengumpulan Data}

Instrumen dalam penelitian ini adalah dalam bentuk kuesioner dari variable independen perubahan perilaku sedangan variable dependen menggunakan lembar wawancara.

\section{Analisa Data}

Data dianalisis berdasarkan skala ukur dan tujuan penelitian dengan menggunakan perangkat lunak komputerisasi. Data dianalisis secara: Analisis Univariat, analisis dilakukan untuk melihat proporsi. Analisis Bivariat, uji bivariat dilakukan untu mecari hubungan antara variabel independen dan variabel dependen dengan uji yang digunaan adalah Chi Square bila memenuhi syarat. Kemaknaan yang diterima apabila $\rho<0,05$.

\section{HASIL}

Berdasarkan tabel 1 maka dapat diketahui bahwa karateristik responden yang berjenis kelamin laki-laki lebih banyak yaitu 20 (62,5\%) responden, dibandingkan dengan yang berjenis kelamin perempuan hanya sebanyak 12 (37,5\%) responden. karateristik responden 
yang berumur 12 tahun hanya $1(3,1 \%)$ responden, yang berumur 13 tahun lebih banyak yaitu $25(78,1 \%)$ responden, dan yang berumur 14 tahun $6(18,8 \%)$ responden.

Tabel 1. Distribusi Frekuensi Berdasarkan Karakteristik Responden

\begin{tabular}{c|cc}
\hline Karakteristik & Frequency (f) & Persent (\%) \\
\hline Jenis Kelamin & & \\
Laki Laki & 20 & $62,5 \%$ \\
Perempuan & 12 & $37,5 \%$ \\
Umur & & \\
12 tahun & 1 & $3,1 \%$ \\
13 tahun & 25 & $78,1 \%$ \\
14 tahun & 6 & $18,8 \%$ \\
\hline Total & $\mathbf{3 2}$ & $\mathbf{1 0 0 , 0}$ \\
\hline
\end{tabular}

Berdasarkan tabel 2 dari 32 responden yang kecanduan game 18 (56,3\%) responden, sedangkan yang tidak kecanduan game $14(43,8 \%)$ responden.

Tabel 2. Jumlah Responden Berdasarkan Kecanduan Game Online

\begin{tabular}{ccc}
\hline Kecanduan Game Online & Frequency (f) & Persent (\%) \\
\hline Kecanduan & 18 & $56,3 \%$ \\
Tidak Kecanduan & 14 & $43,8 \%$ \\
\hline Total & $\mathbf{3 2}$ & $\mathbf{1 0 0 , 0}$ \\
\hline
\end{tabular}

Berdasarkan tabel 3 yang berperilaku positif 14 (43,8\%) responden, sedangkan yang berperilaku negatif $18(56,3 \%)$ responden.

Tabel 3. Jumlah Responden Berdasarkan Perubahan Perilaku

\begin{tabular}{ccc}
\hline Perubahan Perilaku & Frequency (f) & Persent (\%) \\
\hline Perilaku positif & 14 & $43,8 \%$ \\
Perilaku negatif & 18 & $56,3 \%$ \\
\hline Total & $\mathbf{3 2}$ & $\mathbf{1 0 0 , 0}$ \\
\hline
\end{tabular}

Berdasarkan hasil analisis menggunaan Uji Chi Square diperoleh nilai $\rho=0,005<\alpha=$ 0,05 ini menunjukan adanya hubungan antara kecanduan game online terhadap perubahan perilakau dikalangan remaja di SMPN 1 Bulukumba.

Tabel 4. Hubungan Berdasarkan Kecanduan Game Online Dengan Perubahan Perilaku

\begin{tabular}{ccccccccc}
\hline Kecanduan & \multicolumn{4}{c}{ Perubahan Perilaku } & & Total & \multicolumn{1}{c}{$\boldsymbol{P}$} \\
\cline { 2 - 5 } Game Online & \multicolumn{3}{c}{ Perilaku Positif } & \multicolumn{2}{c}{ Perilaku Negatif } & & & Value \\
& $\mathrm{n}$ & $\%$ & $\mathrm{~N}$ & $\%$ & $\mathrm{~N}$ & $\%$ & \\
Kecanduan & 4 & $12,5 \%$ & 14 & $43,8 \%$ & 18 & $56,3 \%$ & \\
Tidak Kecanduan & 10 & $31,3 \%$ & 4 & 12,5 & 14 & $43,8 \%$ & 0,005 \\
\hline Total & $\mathbf{1 4}$ & $\mathbf{4 3 , 8 \%}$ & $\mathbf{1 8}$ & $\mathbf{5 6 , 3 \%}$ & $\mathbf{3 2}$ & $\mathbf{1 0 0 , 0 \%}$ & \\
\hline
\end{tabular}




\section{PEMBAHASAN}

Hasil analisis menggunaan uji statistik Chi Square diperoleh nilai $\rho=0,005<\alpha=0,5$. Berdasarkan hasil akhir tersebut dapat disimpulkan bahwa terdapat hubungan antara kecanduan game online terhadap perubahan perilaku dikalangan remaja siswa SMPN 1 Bulukumba. Hasil penelitian tersebut sejalan dengan penelitian (Wahidah, 2019) dengan judul Hubungan Kecanduan Game Online Smartphone Dengan Perilaku Agresif Siswa MTSN 1 Kampar.

Hasil penelitian ini menunjukkan bahwa terdapat hubungan yang signifikan antara kecanduan game online smarthphone dengan perilaku agresif dengan nilai $\mathrm{R}=0,603$ dan sig $=0,000(\rho<0,01)$. Hal ini berarti hipotesis diterima artinya, terdapat hubungan antara kecanduan game online smarthphone dengan perilaku agresif pada siswa. Penelitian yang dilakukan Jap, Tiatri, Jaya \& Suteja (2013) mengungkapkan bahwa 10,15\% remaja di Indonesia terindiasi mengalami kecanduan Game Online. Hasil penelitian yang dilakukan (Siti Rahmalia D. F., 2016) pada 50 orang responden didapatkan kesimpulan bahwa mayoritas responden mengalami kecanduan bermain Game Online yaitu sebanyak 30 orang responden (88\%) dan mayoritas responden berada dalam status identitas diri atif sebanyak 20 orang responden (90\%), berdasarkan hasil uji statistik Chi Square didapatkan $\rho=0,005>\alpha(0,05)$.

Menurut asumsi peneliti mengatakan pemantauan dalam bermain Game Online merupakan strategi yang paling efetif dikarenakan untuk mencegah pengguna Game Online untuk tidak terlibat dalam penggunaan berlebihan dan disini peran orang tua harus lebih mengawasi anak-anaknya dalam bermaian Game Online karena bisa sangat berpotensi membuat remaja menjadi kecanduan Game online.

Kecanduan Game Online ini dapat memberikan dampak buruk terhadap remaja. Dikarenakan remaja ini dianggap lebih sering dan paling rentan terhadap kecanduan Game Online dan pada masa remaja yang berada pada periode ketidakstabilan, lebih mudah terjerumus terhadap percobaan akan hal-hal yang baru (Jordan \& Anderson, 2016). Akibatnya remaja yang mengalami kecanduan Game Online cenderung kurang tertarik terhadap kegiatan lain, merasa gelisah tidak dapat bermain Game Online sehingga ini akan dapat berdampak buruk pada remaja jika tidak disikapi dengan baik dan gejala lain yang dapat timbul pada remaja yang mengalami kecanduan Game Online terjadinya penurunan prestasi remaja dalam sekolahnya. Menurut (Piyeke, 2014) intensitas remaja yang mengalami kecaduan Game Online dikatakan normal apabila $<3$ jam dan yang tidak normal $>3$ jam. 


\section{KESIMPULAN DAN SARAN}

Terdapat hubungan antara kecanduan game online dengan perilaku pada remaja siswa SMPN 1 Bulukumba. Berdasarkan hasil uji statistik Chi Square dengan nilai $\rho=0,005$. Diharapkan para orang tua harus lebih mengawasi anak-anaknya dalam bermain Game Online karena bisa berpotensi membuat anakana menjadi kecanduan Game Online dan pemantauan orang tua dapat dilakukan dengan menjalin komunikasi yang baik dengan anak, menempatkan berbagai produk teknologi yang mudah diamati, mengetahui keberadaan anak, dll. Hal tersebut dapat mengurangi waktu anak dalam bermain Game Online dan mencegah tingkat kecanduan Game Online yang lebih parah.

\section{DAFTAR PUSTAKA}

Ali, M. and Asrori, M. (2018) Psikologi Remaja Perkembangan Peserta Didik. JakartDonsu, J. D. T. (2019). Metodologi Penelitian Keperawatan. Yogyakarta.

Gunawan, D. (2018). Penerapan Konseling Behavioral Teknik Modelling Untuk Mengatasi Kecanduan Game Online Pada Anak Usia 10 Tahun Didik Gunawan, 5(2).

Hutagaol, B. (2018). Apa Itu Mobile Lagends. Retrieved from http://esportnesia.com/game/mobile-legends/apa-itu-mobile-lagends/

J.Ariati. (2015). ANTISIPASI KECANDUAN GAME ONLINE BAGI SISWA SMK DENGAN GAMING ADDICTION AWARENESS PROGRAMME (GAME), 29-44.

Kevino, S. (2019). Esportsnesia Apa itu Free Fire. Retrieved from https://esportsnesia.com/game/free-fire/apa-itu-free-fire/

Kustiawan, A. A., \& Utomo, A. W. B. (2019). JANGAN SUKA GAME ONLINE PENGARUH GAME ONLINE DAN TINDAKAN PENCEGAHAN. Jawa Timur: CV. AE MEDIA GRAFIKA.

Maramis, W. F. (2010). BUKU AJAR KEPERAWATAN JIWA. Surabaya: AUP.

Masya, H., \& Candra, D. A. (2016). Faktor-faktor yang mempengaruhi perilaku gangguan kecanduan game online pada peserta didik kelas $\mathrm{x}$ di madrasah aliyah al furqon prabumulih tahun pelajaran 2015/2016, 3(1), 153-169.

Mohammad Ali, M. A. (2018). PSIKOLOGI REMAJA. Jakarta: BUMI AKSARA.

Notoatmodjo. (2012). Metodelogi Penelitian. Kesehatan MasyarakatIlmu Dan Seni, Promosi Kesehatan Masyarakat. Jakarta: Rineka Cipta.

Nursalam. (2016). Metodologi Penelitian Ilmu Keperawatan. Jakarta: Salimba Medika.

Raafani, T. (2018). Free Fire Battlegrounds, Battle Royal Dalam Smartphone. Retrieved from http://www.kincir.com/game/mobile-game/review-free-fire-battlegrounds 
Rahma, A., Psikologi, P. S., Psikologi, F., \& Surakarta, U. M. (2018). Interaksi sosial pada remaja kecanduan game online.

Seo, S. C. B. (n.d.). penggunaan smartphone dan kecanduan smartphone pada siswa menengah sekolah di Korea: Prevalensi , layanan jejaring sosial, dan penggunaan permainan. https://doi.org/10.1177/2055102918755046

Setiadi. (2013). Konsep Dan Praktek Penulisan Riset Keperawatan. Yogyakarta: Graha Ilmu.

Setiawan, J. (2019). Tips Bermain Free Fire. Retrieved from http://www.kabargames.id/tipscara-main-free-fire-ff-pemula-sampai-pro/

Siahaan, S. (2019). Cara Bermain dan Tips Penting Seputar Mobile Lagends: Adventure. Retrieved from http://www.tokopedia.com/blog/game-mobile-legends-adventure/

Sugiyono. (2014). STATISTIKA UNTUK PENELITIAN. Bandung: ALFABETA.

Syahran, R. (2015). Ketergantungan online game dan penanganannya, 1, 84-92.

Wajo, K., Selatan, S., Online, K. G., \& Bimbingan, M. (2019). Peran Bimbingan Konseling Islam Mengatasi Kecanduan Game Online The Role of Islamic Counseling Guidance Overcomes Online Game Addiction, 18(1), 802-810.

Zulfan Saam, S. W. (2013). PSIKOLOGI KEPERAWATAN. Jakarta: PT Raja Grafindo Persada.a: PT Bumi Aksara. 